\title{
What lies beneath the skin
}

\author{
Mrisa Sahai, Alyce M Oliver
}

Department of Medicine, Georgia Health Sciences University, Augusta, Georgia, USA

\section{Correspondence to} Dr Alyce M Oliver, aloliver@georgiahealth.edu

\section{DESCRIPTION}

A 46-year-old man with a history of hypertension presented with a 6-month history of progressive, diffuse skin thickening. He denied any exposure to new drugs, toxins or contrast material, had no history of Raynaud's disease or endocrine disorder. Physical examination revealed diffuse skin tightness, limited range of motion of joints and sparse hair with leonine facies (figures 1 and 2). A skin biopsy revealed fibroblast proliferation (figure 3) and special staining with Alcian Blue (figure 4) revealed an increased mucin between and among collagen bundles resulting in the diagnosis of scleromyxedema. Further work-up revealed a bone marrow biopsy consistent with a plasma cell dyscrasia. Patient was subsequently treated with dexamethasone, bortezomib and thalidomide resulting in stabilisation of skin fibrosis and resolution of plasma cell dyscrasia.

Scleromyxedema is a rare connective tissue disorder that has been associated with paraproteinemias. It is characterised by cutaneous eruption of small, waxy, firm papules commonly occurring over

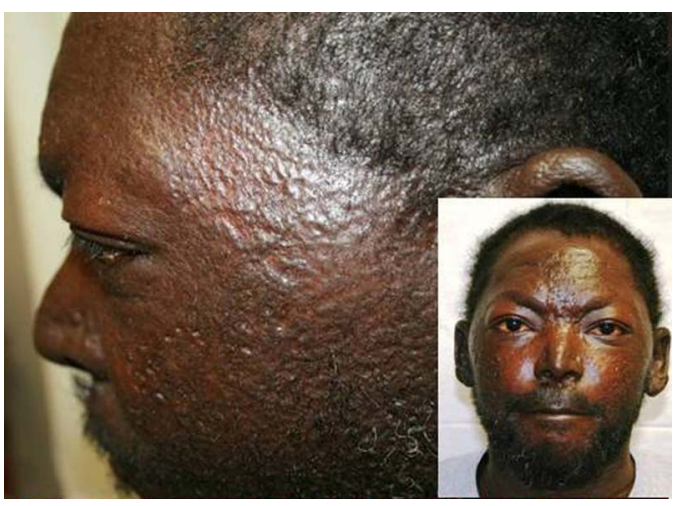

Figure 1 Diffuse papular waxy skin eruption of the face.

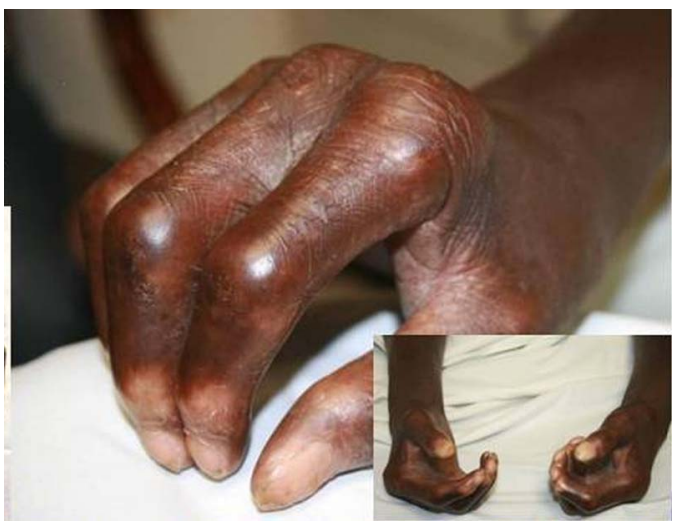

Figure 2 Diffuse skin tightening, loss of digital pulp and hypopigmentation of the distal fingers in the absence of nailfold capillary changes.

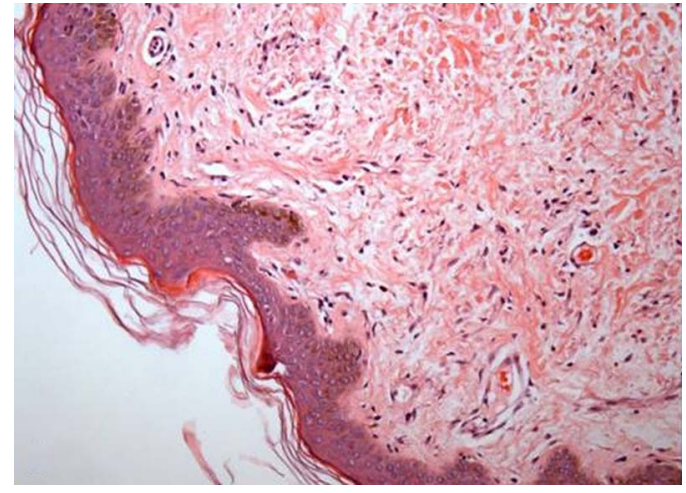

Figure 3 Skin biopsy showing within the dermis a proliferation of spindled fibroblasts and histiocytes in association with scattered lymphocytes.

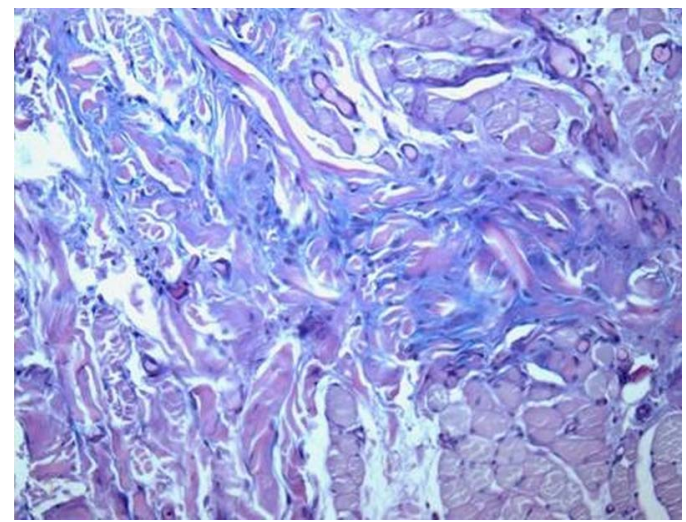

Figure 4 A special stain for mucin (Alcian Blue) revealed an increased mucin between and among collagen bundles.

thickened and indurated skin. Histologically, there is a cutaneous deposition of mucin in the superficial dermis and fibroblast proliferation. The presence of a monoclonal protein, often $\operatorname{IgG}-\lambda$, supports the diagnosis of scleromyxedema. ${ }^{1}$ Treatment with thalidomide, melphalan or highdose intravenous immunoglobulin may reduce the paraprotein. $^{2}$

\section{Learning points}

- The differential diagnosis for skin thickening extends beyond systemic sclerosis.

- Patients with a diagnosis of scleromyxedema should undergo bone marrow biopsy to rule out paraproteinemia.

- In patients with scleromyxedema treating underlying paraproteinemia improves skin fibrosis. 
Competing interests None.

Patient consent Obtained.

Provenance and peer review Not commissioned; externally peer reviewed.

\section{REFERENCES}

1 Kitamura W, Matsuoka Y, Miyagawa S, et al. Immunochemical analysis of the monoclonal paraprotein in scleromyxedema. J Invest Dermatol 1978;70:305.

2 Cokonis Georgakis CD, Falasca G, Georgakis A, et al. Scleromyxedema. Clin Dermatol 2006;24:493.

Copyright 2013 BMJ Publishing Group. All rights reserved. For permission to reuse any of this content visit http://group.bmj.com/group/rights-licensing/permissions.

BMJ Case Report Fellows may re-use this article for personal use and teaching without any further permission.

Become a Fellow of BMJ Case Reports today and you can:

- Submit as many cases as you like

- Enjoy fast sympathetic peer review and rapid publication of accepted articles

- Access all the published articles

- Re-use any of the published material for personal use and teaching without further permission

For information on Institutional Fellowships contact consortiasales@bmjgroup.com

Visit casereports.bmj.com for more articles like this and to become a Fellow 